\title{
THIRTY YEARS LATER \\ Past, Present and Future of Editing the Basilica
}

\section{Introduction}

It is now thirty years since the last volume of the 'Groningen edition' of the Basilica was published. The edition has been out of print for at least ten years now, but has recently been made available online through Brill, ${ }^{1}$ who bought the rights from the original publishers. Text and scholia have already been accessible in digital form for some time through the databank Thesaurus Linguae Graecae of Irvine, but without critical apparatus and prefaces, and with a different length of the lines of fragments, which may create confusion when referring, especially to longer fragments. With the new digital format, those who prefer to consult a digital edition will no longer need to worry about differences, and they will also be able to inform themselves about the editorial choices that lie at the base of the edition.

What was and still is lacking in the printed edition as well as now in the online format is Prolegomena to the entire work. In 1981 the preparations of the last volume had been completed. Two weeks later Herman Jan Scheltema (1906-1981), the auctor intellectualis and guiding spirit of the enterprise, passed away. His younger colleagues Douwe Holwerda (1920-2011) and Nicolaas van der Wal (1925-2015), who had participated in the editorial work from its early stages, saw the last volume through the press, which then was presented in $1988 .{ }^{2}$ They concluded their Praefatio, as always in Latin, as follows: ${ }^{3}$

In the prefaces of the preceding volumes we used to announce the next volume. At this place, however, we gratefully inform the reader that the edition of text and scholia, the preparation of which Scheltema had begun about the year 1945, has been completed. We are even more

1 http://referenceworks.brillonline.com/browse/basilica-online.

2 The proceedings of the 1988 conference celebrating the publication of the last volume (A VIII) were published in Subseciva Groningana III (1989).

3 I have translated all quotations from the Latin praefationes into English. 


\section{STOLTE}

grateful for the fact that he - as we have already told the readers in the preface of volume B VIII $^{4}$ - before his death in December 1981, knew that he need no longer doubt - as at the time when he had made a beginning with this immense task - that the edition begun by him would be brought to an end.

Even after the completion of the edition some things remain for us to be done. That we would add a volume containing Prolegomena we have already announced more than once. Moreover, we intend to prepare a supplement, in which we publish those texts that pertain to the Basilica, but could not be included in the volumes of the edition. Among these are the unauthentic preface of the Basilica; the text of the first book which diverges from the customary form in cod. Par. Coisl. gr. 151 and is found in a summarised version in cod. Par. gr. 1352; and the indices of all the titles of the Basilica preserved in the same codex Coislinianus as well as in the codex Ath. Pantocr. 234. Perhaps in that supplement should also be inserted a more complete and improved reconstruction of book LIII, which we are now able to accomplish, after our Frankfurt colleagues [note of H\&vdW: "Cf. D. Simon, Handschriftenstudien zur byzantinischen Rechtsgeschichte, Byz. Zeitschr. 71 (1978) pp. 332-348 (and especially pp. 340-343)"] have found the manuscript, given up by the learned world, from which Francesco Venturi in 1604 has taken the texts of the Basilica that he translated into Latin. That codex is indeed most probably Vat. Barb. 578. The time, however, that these two volumes will appear we do not to dare to announce at the moment.

The words of Van der Wal and Holwerda are in fact Scheltema's programme as stated at the beginning of the project, ${ }^{5}$ with the addition of book LIII, of which we now have the edition by Rhodolakis. ${ }^{6}$ Unfortunately, they did not live to produce the two volumes as intended. With the death in 2015 of the last surviving member of the editorial equipe, the task of providing them had definitively fallen to the next generation, and the present author could

At the end of the Praefatio of B VIII, which had been signed by all three editors and dated on 2 December 1981, Holwerda and Van der Wal wrote the following praefationis additamentum: 'On November 18th, 1981, we have formally offered to our illustrissimus and, to us carissimus, teacher Herman Jan Scheltema the last part of the copy, prepared for the press, of this edition. Two weeks later, on the very day on which this preface has been dated, after he had spent the entire day studying, he suddenly died in the evening. We are glad that he has seen the result of the immense work, but regret, that it has not fallen to him to write the prolegomena to edition. We hope, however, that the notebooks that he left will assist us in the completion of this part of the work.'

5 That is, Prolegomena as well as a volume with Appendices. See A I, Praefatio, p. XI.

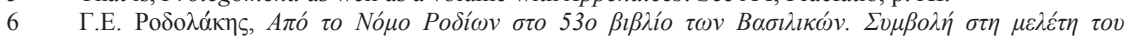

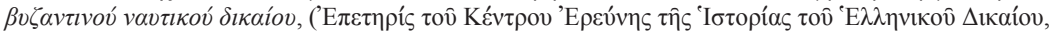

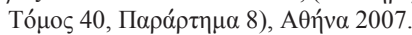


not but feel humbled and honoured before the task that he faced ${ }^{7}$ when asked to provide an introduction to the digital edition. The result is a preface of some thirty pages, ${ }^{8}$ to which I will refer as 'Stolte, Praefatio 2017'.

As I pointed out on its opening page, that was at best 'an interim report' on the way to proper Prolegomena and could not pretend to be their substitute. It aimed at providing a more convenient format for the information that could be found for the greater part in the praefationes of the seventeen volumes of the edition and in the papers of Scheltema, ${ }^{9}$ Holwerda and Van der Wal. ${ }^{10}$

The perspective of the present paper is different. It sets out in greater detail some of the points concisely dealt with in Praefatio 2017 or treated not at all where I felt this would be out of place in an introduction to a critical edition that moreover had not been made by the person writing that introduction. In other words, this paper is to be understood as a supplement to Praefatio 2017, to which the reader is referred throughout.

\section{The past}

\subsection{C.A. Fabrot (1580-1659)}

Praefatio 2017 briefly describes the efforts of previous editors. ${ }^{11}$ Hans Erich Troje has written the early history of the scholarly efforts to gain entry into the warehouse of Byzantine legal texts and to exploit these for contemporary, western law. It is a fascinating story of the gradual discovery of manuscripts, the difficulty of getting Greek texts published, the necessity to translate those texts into Latin. ${ }^{12}$ The names of Viglius, Leunclavius, and Cuiacius, to name but three, are prominent in that story. Here my concern lies with the first milestone

7 Again I am indebted to all members past and present of the Groningen Department of Legal History, especially those whom I have pestered with questions while writing. The responsibility for the result is the author's alone.

8 B.H. Stolte, Praefatio 2017, http://referenceworks.brillonline.com/browse/basilica-online\#browse-tab-1. See also the Bibliography by Th.E. van Bochove, http://referenceworks.brillonline.com/browse /basilica-online\#browse-tab-2.

9 H.J. Scheltema, Opera minora ad iuris historiam pertinentia. Collegerunt N. van der Wal, J.H.A. Lokin, B.H. Stolte, Roos Meijering, Groningen 2004.

10 His collected papers are being edited by Th.E. van Bochove.

11 Stolte, Praefatio 2017 (note 8 above), sections 4: 'Previous editions' and 6: 'Summing up: the differences'; cf. also Heimbach, Prolegomena, 176-186.

12 H.E. Troje, Graeca leguntur. Die Aneignung des byzantinischen Rechts und die Enstehung eines humanistischen Corpus iuris civilis in der Jurisprudenz des 16. Jahrhunderts, (Forschungen zur neueren Privatrechtsgeschichte, Band 18), Köln / Wien 1971. 
and editio princeps of the Basilica, the edition by C.A. Fabrot. Its printing took six years for the seven volumes to appear all together in Paris in $1647 . .^{13}$ Their publication is a splendid achievement and a jewel in the crown of seventeenth-century printing in France. For the Basilica it was to remain the point of reference for almost two centuries. What did it offer exactly? For an answer we have to look at philological scholarship in its time and focus on two aspects of editing Byzantine legal texts in the context of that period: editing classical texts in general in the sixteenth and seventeenth centuries, and the motive of editing Byzantine legal texts at all.

First, editing classical texts in the early modern period. I cannot recommend warmly enough the illuminating pages of Kenney's 'The Classical Text'. ${ }^{14}$ For the present purpose it suffices to refer to what Kenney calls 'the false problem':

The aim which a modern editor proposes to himself, of establishing the text (whatever method or technique of recension he may choose) was for them [i.e., the scholars of the sixteenth century] unattainable and as yet indeed incomprehensible. For that they lacked the basic materials - the evidence itself - even had they possessed the techniques; but the latter qualification is idle, for apprehension of the techniques could come only from the discovery and understanding of the materials. ${ }^{15}$

Kenney here describes ' $[t]$ he problem immediately confronting the successors of the earliest editors, the men of the post-editio princeps age [... as] a false problem' [ibidem]. The invention of the printing press had created multiple uniform copies. They were the first step to a textus receptus, and the successors of the first editors tinkered with the text with tools as happened to be available. But these first editors had, of course, been themselves as restricted in their means as their successors. The situation described in the statement quoted above had led to a series of editiones principes of classical texts usually based on just the one manuscript that happened to be at hand, and printed with some corrections inspired by the ingenium of the scholar in charge. Improvements were possible as and when other manuscripts were discovered (codicum ope), or just with the help of a different brain (ingenii ope). Not until the nineteenth century did a truly systematic recension become possible. This

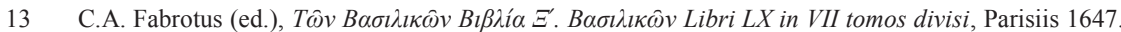
The short-title is almost an insult to the actual volumes.

14 E.J. Kenney, The Classical Text: Aspects of Editing in the Age of the Printed Book, (Sather Classical Lectures, Vol. 44), Berkeley etc., 1974.

15 Kenney, The Classical Text (note 14 above), 19. 
held good of Latin as well as of Greek texts; scholarship of Greek, not to speak of Byzantine, texts generally lagged behind that of Latin texts.

Second, the motive of editing Byzantine legal texts. From the beginning this motive was awareness of the potential of Byzantine sources for the knowledge of the Roman, predominantly Latin, legal texts and their interpretation. They offered a new fount of criticism of the Justinianic texts, and for that reason, and no other, were they studied, edited and translated, and not necessarily in that order. Crucially, these Byzantine texts were measured against the Roman texts. Indeed, more than once a Latin text inspired a conjecture of the Greek text at hand. As we shall see, the process of editing a Byzantine fragment was hardly ever kept separate from its Roman ancestor.

The consequences of these two factors must not be underestimated. Indeed, the first, the 'false' problem, was compounded by the second and in combination they seriously impaired the prospect of producing what we now consider to be a critical edition.

The Basilica edition of Fabrot is a case in point. The preliminaries of the first volume provide a fairly clear picture of the circumstances in which Fabrot worked. They consist of a dedicatory epistle to Pierre Séguier, Chancellor of the King of France; a preface to the reader; a brief pamphlet by Joseph Maria Suaresius on the Basilica; and finally, Testimonia veterum de libris Basilic $\hat{\omega}$, five extracts from Byzantine authors in which the Basilica are mentioned.

The dedication, dated on November 1st, 1646, gives Séguier all the honour he has deserved by promoting and financing the enterprise: he has paid for the acquisition of manuscripts and other costs. Fabrot mentions almost in passing the nature of the Basilica: they are the Corpus iuris civilis in Greek translation, issued by Leo VI, in which parts that had become obsolete had been omitted. Praise is bestowed on Cuiacius for making known, indeed giving fame to this treasure; but this would have been in vain if not, after the death of Cuiacius, Séguier had made possible the present edition: 'at Your expense it has been translated into Latin and published' (sumptibus Tuis Latine conversum et publica luce donatum). The Basilica represent Roman law, which has been adopted by the King of France where custom or statute were lacking. The rest of the dedication is a panegyric on the King and his Chancellor Séguier, not to forget the Chancellor's library.

Before we turn our attention to Fabrot's introduction, we cast a brief look at a curious insert. It is a brief treatise on the Basilica, written by Suaresius for an entirely different purpose, a pamphlet originally published in Rome in 1637 and addressed to Pope Urban 


\section{STOLTE}

VIII. ${ }^{16}$ As becomes clear in its last two paragraphs, its purpose was to induce the Pontiff to pay for a Roman edition of the Basilica. With the insertion of this 'anspruchslose Gelegenheitsschrift eines an der byzantinischen Forschung kaum beteiligten Autors', as Troje dismisses its merit, ${ }^{17}$ Fabrot saved himself the trouble of giving a more detailed description of the Basilica, while at the same time, since the Roman Pontiff had not come forward, silently demonstrating the superiority of the French King as a patron of the Arts. Fabrot simply had Suaresius' text printed, which had been sent to him by Cardinal Franciscus Barberini, as a note in the margin states. Fabrot's sole contribution consisted in providing some annotations consisting of no more than indications of the content, the last one being a laconic statement that 'these books of the Basilica, bought up by the Most Christian King, have now

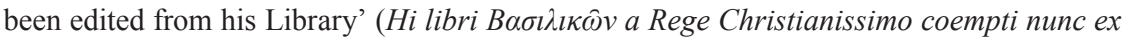
eius Bibliotheca editi sunt).

It is Fabrot's preface Lectori, ${ }^{18}$ then, that is informative about his approach to editing. Almost every single fragment has been edited and translated on the basis of just one manuscript, on the understanding that no less than a quarter of the sixty books had been lost:

... the Basilica, divided into sixty books ... have not reached us in full, but only forty-one books. Books 19 and 31 up to 38, and 43, 44 and 49 up to 60 have been lost, unless they happen to hide on the shelves of some library or other. ${ }^{19}$

This confirms the availability to Fabrot of five manuscripts from the Royal Library: Paris. gr. 1352 (P, books 1-18,2); 1348 (Pa, 20-30,1); 1345 (Pb, 38-42), 1349 (Pc, 45-48), and $1350(\mathbf{P e}, 60),{ }^{20}$ Fabrot also consulted a 'Codex Riberii', later also acquired by the Royal Library and given the shelf-mark Paris. gr. $1354 .{ }^{21}$ In order to constitute as complete as possible a text, Fabrot had to fill huge gaps:

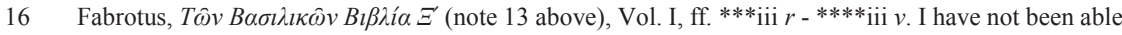
to find a separate pamphlet. See Troje, Graeca leguntur (note 12 above), 277-278.

17 Troje, Graeca leguntur (note 12 above), 278.

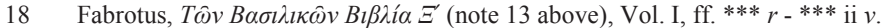

19 In reality they are only thirty-nine; see also Heimbach, Prolegomena, 182. For the manuscripts and their sigla in the Groningen edition, see Stolte, Praefatio 2017 (note 8 above), section 3: 'The manuscript tradition of the Basilica'.

20 Not accessible to Fabrot, because not yet in the Royal Library, was the present Paris. gr. 1357 (Pd, 4652). It was to be used indirectly by Reitz (see below, p. 174).

21 Fabrotus, Lectori (note 18 above), f. *** ii $r$, and see Heimbach, Prolegomena, 172. The manuscript (see RHBR, I, No. 168) was written in Rome in 1556; it has a complicated pedigree and contains books 28-29 and 45-48. It was eliminated by the Groningen editors as ultimately going back to Laur. 80.11 (F) and Paris. gr. 1349 (Pc). 
We have healed this wound and disgrace [the lacunae] of a very beautiful work insofar as possible, and have supplied the parts that are lacking in the books of the Royal Library from the Synopsis Basilicorum, both in printed and in manuscript form, from Theodore of Hermopolis, not yet published, or from Constantine Harmenopoulos, compared with royal manuscripts, or from scholia of the Basilica (ex glossis Basilicon), or finally from the commentaries of the most distinguished Cuiacius on the last three books of the Code.

In other words, Fabrot recognized these sources as helpful for filling the gaps, but without going into their nature and value, or explaining his method. The result is an edition made almost entirely on the basis of codex unicus and editorial ingenium, the latter often inspired by wishful thinking, since the ultimate goal was 'improvement' of the Corpus iuris. Interestingly, when Fabrot mentions that he was under great pressure of preparing copy for the press, he is not thinking of the Greek text, but rather of the translation:

One thing, however, I urgently request, dear reader, that you will not measure our translation (versionem) against a strict standard; it was crafted (elaboratam) while the press was always running, indeed sometimes even two. Even in a great work it is permitted (fas) that a person is surprised by sleep, and "never making a mistake is the province of the gods rather than of mankind", as Justinian [const. Tanta, § 13] wisely warns.

The emphasis on the translation rather than on the edition is also proclaimed by the titlepage: '... Carolus Annibal Fabrotus, Dean of the Professors (Antecessorum) of Aix-enProvence, has translated into Latin and edited in Greek, from the library of the Most Christian King'. We may safely assume that the constitution of the text was not exactly a work of leisure. The haste in which the seven volumes had been seen through the press is also clear from the concluding words of the preface Lectori:

... For it has not been given to me to reread at leisure (per otium) the seven volumes. I say seven volumes, for the typesetters (operae typographicae) believed that these could not easily be divided into $\tau \varepsilon \dot{\chi} \chi\rceil ~ \check{~} \check{\xi}$. If, however, we will still be alive and God will have created this leisure for us, we will correct mistakes, whether they are accidental or due to the evil of haste, and perhaps there will be no reason for anyone to find our diligence wanting.

The reader may be excused for thinking that Fabrotus was fully aware of defects of his edition, but that is not all. He was measuring himself against the standard of editorial work of his time. What we see, more than 350 years later and against the different standards of 
modern philology, is on the one hand a weak base of evidence and on the other hand haste and an emphasis on translating; not exactly a promising combination for the constitution of the Greek text.

As to the translation, it is worth looking at what Fabrotus has to say on this point. His most important predecessors were Leunclavius and Cuiacius. Leunclavius (1541-1594) had been the first to claim to have edited the Basilica, accompanied by a Latin translation. ${ }^{22}$ On closer inspection he correctly mentions not the Basilica themselves, but a 'selection' from them, which is known in modern literature as the Synopsis Basilicorum Maior and from which he reconstructed as far as possible the Basilica. ${ }^{23}$ This is what Fabrotus has to say on Leunclavius as a translator:

Leunclavius, a man not generally known as a great jurist (vir de Jurisprudentia quoque non vulgariter promeritus), had sometimes been rather unfortunate in his translation of that Synopsis. We, who are not in the habit of pursuing anyone with insults, have substituted our translation there, on the understanding that we rather wish it to be up to the judgment of the reader which one he prefers. For example, of Synopsis book 35, title 3, p. 326, Leunclavius

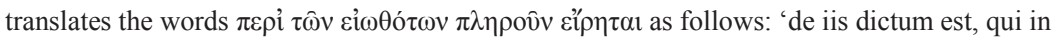
supplementum mitti solent', whereas it should have been translated as 'de iis dictum est qui stipendiis impletis mitti solent', as we have translated in book 35 of the Basilica, title 21, chapter 25.There are a good many other passages that were in need of emendation, and that we have corrected, without the intention of carping at him (citra eius carpendi studium). In the translation of Cuiacius, which was available for the books of the Code mentioned above, ${ }^{24}$ we have changed nothing, since it is very correct. Wish that the same scholar, unquestionably

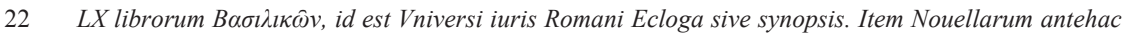
non publicatarum liber, Basileae, per Eusebium Episcopium \& Nicolai Fr. hered., 1575.

23 The SBM is an anthology from the Basilica under key words that had themselves been arranged alphabetically. Leunclavius edited from a manuscript of the SBM, but rearranged the SBM into the order of the sixty books of the Basilica from which it had been compiled; this was not difficult to accomplish, since the Synopsis quotes book, title and chapter of the Basilica with the extracts. See Troje, Graeca leguntur (note 12 above), 264-268; B.H. Stolte, 'Joannes Leunclavius (1541-1594), Civilian and Byzantinist?’, in P.J. du Plessis / J.W. Cairns (eds.), Reassessing Legal Humanism and its Claims. Petere fontes?, Edinburgh 2016, 194-210, esp. 197-198.

24 Cuiacius' commentary on the last three books of the Code made extensive use of Byzantine texts, also from books of the Basilica of which he had a manuscript that has since been lost, and which he often also translated. It first appeared in a composite volume: Ad tres postremos lib. Cod. Iustiniani Commentarii ... Eiusdem [Iacobi Cuiacii] Commentarii in Tit. Pandectarum de verborum obligationi-

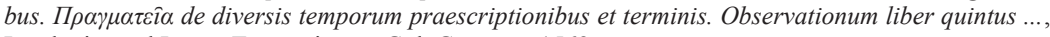
Lugduni: apud Ioann. Tornaesium et Gul. Gazaeum,1562. 


\section{THIRTY YEARS LATER}

the foremost of the jurists, had undertaken to translate all sixty books, and had completed the enterprise! Then we would not have had so much trouble, on account of manuscripts ruined by decay, and letters vanishing by their age.

Then there is a special mention for book 60 , which had been translated by Cuiacius and published without the Greek text. ${ }^{25}$ Here Fabrotus confessed himself to be not entirely sure about the antecedents of his manuscript. In the same passage he mentions books 38-39, where the edition gets some attention:

We have edited (recensuimus) the sixtieth book relying on the royal book (ex fide libri regii [i.e., Paris. gr. 1350]), which is either better than the one Cuiacius has used, or his assistant (eius amanuensis) had skipped a lot in copying that manuscript. The same applies to books 38 and 39, which the most learned Carolus Labbaeus ${ }^{26}$ had edited in Latin. In short, we have compared all books with the Greek ones, and thanks to the additional valuable material (non poenitenda accessione) show them now in better shape.

The emphasis remains on translating, for Fabrotus continues:

On books $28,29,45,46,47,48$, which Gentianus Hervetus ${ }^{27}$ had translated into Latin, I will only say this, that Hervetus was a very learned man, but not in the law, so that I have preferred to translate them in full rather than correct his translation. Cuiacius had already sufficiently pointed out in his erudite preface to book 60 what he had missed in that kind of translation. We have tried to present a better one.

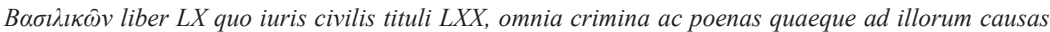
variaque iudicia spectant, continentes, veterum Graecorum iurisconsultorum scholiis explicantur Iacobo Cuiacio I.C. interprete, Lugduni: Ad Salamandrae apud Claudium Sennettonium, 1566.

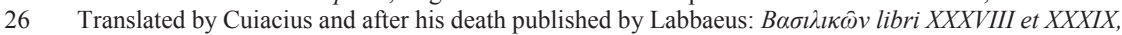
quibus iuris civilis tituli XXXI tutelas, curationes et testamenta continentes, veterum Graecorum Iurisconsultorum scholiis explicantur. Iac. Cujiacio IC. interprete. Ex eiusdem autographo Carolus Labbaeus nunc primum edidit et recensuit, Parisiis: ex officina Nivelliana apud Bastianum Cramoisy, 1609.

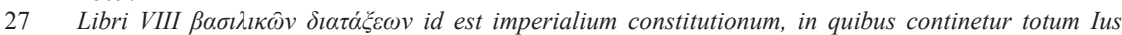
Civile, a Constantino Porphyrogeneta in LX libros redactum, Gentiano Herveto interprete. Lutetiae Parisiorum: apud Arnulphum L'Angelier, 1557 [not seen]. Cf. Troje, Graeca leguntur (note 12 above), 255-256. 
Then Fabrot continues:

However, I can say sincerely that his work has not been entirely useless to us, but at certain points has also provided assistance; but since his manuscript (liber eius) had been imperfect, if it had not been for the book of the Royal Library and the manuscript codex of D. Riberius, Count of the Consistory, it would be necessary to leave the very large lacunae, which had marred the abovementioned books 28 and 29.

If this may be held to pertain at least also to the edition, then the next sentences are again on translating:

For the translation of Justinian's Novels I have occasionally used the old translator (veteri interprete), true, a barbarian, but one in whose lecture I am not sorry to have spent good hours. ${ }^{28} \mathrm{I}$ have also used Gregorius Haloander, ${ }^{29}$ whose translation undoubtedly is purer. Finally, [I have also used] Julianus Antecessor, of the Novels rather an epitomator than a translator. For it is ungenerous not to admit persons of whom one has profited.

These, then, were Fabrotus' sources. He followed in principle one Greek manuscript only, tried to fill lacunae from other sources and added a Latin translation, in part by making his own, in part by borrowing from other translations. The emphasis is on the relation with the Corpus juris civilis and the necessity of a Latin translation, to the extent that Fabrotus has even been noticed to fill Greek lacunae where a Justinianic Latin passage was available by translating that Latin into Greek. ${ }^{30}$ In his defense it must be said that in most cases only one Greek manuscript was known. It is, however, obvious that he wished to provide a collection which would serve a better understanding of the Corpus juris.

For two centuries Fabrotus' edition reigned supreme. It formed the starting-point of all subsequent work. Two substantial contributions were made in he Netherlands, by Reitz

The so-called Authenticum, which is in fact originally a sixth-century kata poda translation of the Greek Novels. It became a fixed part of the medieval Corpus iuris civilis and also faces the Greek text in the standard edition of Justinian's Novels by Schöll and Kroll.

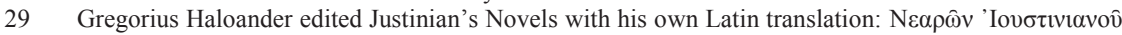

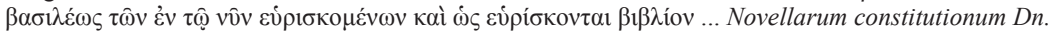
Iustiniani principis quae exstant et ut exstant volumen .... Gregorio Haloandro interprete, Norimbergae, apud Io. Petreium, 1531.

30 N. van der Wal, 'Probleme bei der Restitution verlorengegangener Basilikenbücher', SG III (1989), 143-154, esp. 143. 
and Ruhnkenius. Both filled lacunae in, and thus improved on, Fabrotus' edition. In both cases the book collector Gerard Meerman played a role.

David Ruhnkenius (1723-1798) edited the eighth book of the Basilica from the Leiden manuscript Voss. gr. Fol. 19 [V]. Or rather, that is what he discovered he was doing while working on an edition of commentaries of a number of Byzantine jurists occurring in that manuscript. The details have been set out by Elfriede Hulshoff $\mathrm{Pol}^{31}$ who was preparing her doctoral dissertation at the same time when Scheltema was preparing the first volume of his Basilica edition (B I) in which the scholia of this book are found. Fabrot had edited this book from Paris. gr. 1352 [P], and the scholia in the Vossianus formed a much richer apparatus than those in the Parisinus. Although Ruhnkenius thus supplemented and improved on Fabrotus' edition, his rendering of the manuscript still left much to be desired. ${ }^{32}$ Gerard Meerman had meant it to be included in the first volume of his Novus Thesaurus, ${ }^{33}$ but was not yet ready by then and the first part with the title De postulando (B. VIII,1) appeared in vol. iii, ${ }^{34}$ with the promise in the preface that the second part, with De procuratoribus et defensoribus (B. VIII,2) would soon follow. This promise was made good in vol. v. ${ }^{35}$ Both volumes of the Novus Thesaurus appeared in the same year 1752, when Ruhnkenius' two parts were also published together as a separate volume with the same imprint. ${ }^{36}$ They appeared again in the Operis Basilici Fabrotiani supplementum of $1765,{ }^{37}$ together with Reitz's edition described in the next paragraph. The result is that Fabrot had published text

31 E. Hulshoff Pol, Studia Ruhnkeniana. Enige hoofdstukken over leven en werk van David Ruhnkenius (1723-1798), [PhD Leiden], Leiden 1953, esp. ch. iii, 'Juridisch werk van Ruhnkenius' (87-106).

32 Hulshoff Pol, Studia Ruhnkeniana (note 31 above), 104-106.

33 Novus thesaurus juris civilis et canonici ..., ex collectione et musaeo Gerardi Meerman ..., 7 vols., Hagae Comitum: apud Petrum de Hondt, 1751-1753. (See R. Feenstra / D.J. Osler, Bibliography of Jurists of the Northern Netherlands Active Outside the Dutch Universities to the Year 1811, (Geschiedenis der Nederlandsche Rechtswetenschap. Deel VII: Bibliografie Nederlandse Rechtswetenschap tot 1811, Aflevering 5), Amsterdam 2017 [further referred to as Feenstra / Osler, BGNR Jurists], Nos. 513-519).

34 Feenstra / Osler, BGNR Jurists (note 33 above), No. 674.

35 Feenstra / Osler, BGNR Jurists (note 33 above), No. 675.

36 Feenstra / Osler, BGNR Jurists (note 33 above), No. 673.

37 Operis Basilici Fabrotiani supplementum continens libros quatuor Basilicorum IL, L, LI, LII, nunc primum ex Codice manuscripto Regiae Bibliothecae Parisiensis integre editos: Latine vertit, variantes lectiones collegit, notasque criticas ac juridicas, tam aliorum quam suas, addidit Gul. Otto Reitz JCtus. Accedunt Thalelaei, Theodori, Stephani, Cyrilli. aliorumque JCtorum Graecorum commentarii in Tit. D. \& Cod. de Postulando sive de Advocatis, nec non de Procuratoribus \& Defensoribus, novissime ex Codice MS Bibliothecae Luduni-Batava edidit, Latine vertit \& castigavit David Ruhnkenius, Lugduni Batavorum, Apud Wetstenium 1765 [Feenstra / Osler, BGNR Jurists (note 33 above), No. 653]. 
and scholia from $\mathbf{P}$ and Ruhnkenius the text with more numerous scholia from $\mathbf{V}$. We shall return to the editorial history of book VIII below. ${ }^{38}$

Gulielmus Otto Reitz (1702-1768) filled another lacuna. Reitz is probably better known for his splendid edition of the Paraphrasis Institutionum of Theophilus. ${ }^{39}$ As rector of the Athenaeum Illustre in Middelburg he had to work from copies and collations made by others. Taking this limitation into account, he produced excellent results. As has been said above, Fabrot did not yet have access to the manuscript that was to become Paris. gr. 1357 and contained books 46-52 (Pd). Gerard Meerman acquired a copy made from that manuscript and Reitz, at the request of Meerman, used it to edit books 49-52, books that had been reconstructed by Fabrot from other sources. Meerman included it in vol. $\mathrm{v}$ of the Novus Thesaurus ${ }^{40}$ and it was reprinted in the Operis Basilici Fabrotiani supplementum. ${ }^{41}$

The title Operis Basilici Fabrotiani supplementum that was given to the joint publication of 1765 of Ruhnkenius' and Reitz's work is significant in two respects. It is precisely what it says: it should be understood, as did also the editors, as a supplement to Fabrot's edition. Both Ruhnkenius and Reitz had little reason to question that edition: both had found a manuscript transmitting a part of the text of the Basilica not yet available to Fabrot. Chance had yielded two manuscripts, which Ruhnkenius and Reitz then used to fill lacunae in the existing edition in typical Humanist fashion. Reitz had a firmer grasp of the legal content of the text and probably was a better philologist that Ruhnkenius. ${ }^{42}$

This, then, was the state of the text when a new edition was undertaken in Germany in the first half of the nineteenth century.

\subsection{C.W.E. Heimbach (1803-1865)}

This was the status editionis et quaestionis in 1825, when Karl Wilhelm Ernst Heimbach, twenty-two years old, published his programme under the title De Basilicorum origine, fontibus, hodierna conditione atque nova editione adornanda.$^{43}$ The first volume of the edition

38 See section 3 sub a, pp. 181-182 below.

39 J.H.A. Lokin / R. Meijering / B.H. Stolte / N. van der Wal (edd.), Theophili Antecessoris Paraphrasis Institutionum. With a translation by A.F. Murison, Groningen, 2010, pp. xxxix-xli.

40 Basilicorum libri quatuor, IL, L, LI et LII ex codice manu scripto Regiae bibliothecae Parisiensis nunc primum integre editi. Latine vertit, variantes lectiones collegit, notasque criticas ac juridicas, tam aliorum quam suas, addidit Gul. Otto Reitz, JCtus, in Meerman, vol. v [Feenstra / Osler, BGNR Jurists (note 33 above), No. 651].

41 Feenstra / Osler, BGNR Jurists (note 33 above), No. 653.

42 For Ruhnkenius see again Hulshoff Pol, Studia Ruhnkeniana (note 31 above), 104-106.

43 Doctoral dissertation, Leipzig 1825 (not seen). 
appeared in 1833 , the fifth and final one in 1850 . In addition to the five volumes, two supplements (1846 and 1897) and a volume with Prolegomena and a Manuale Basilicorum (1870) were published. Together they are often, somewhat inaccurately, described as the Heimbach edition. The main differences between Fabrot's and Heimbach's editions have been set out by Heimbach himself. A great step forward was the use of the Coisliniani, which gave the text a much firmer foundation.

In the meantime another German, nine years his junior, had entered the stage, Carolus Eduardus Zachariae a Lingenthal (K.E. Zachariä von Lingenthal), ${ }^{44}$ who was going to dominate nineteenth-century scholarship in Byzantine law. In 1842 he wrote a review of Heimbach's first two volumes ${ }^{45}$ and in 1846 published a revised edition of books XV-XIX, which he gave the title of Supplementum editionis Heimbachianae. ${ }^{46}$ It was based on a palimpsest manuscript, which he had discovered in Constantinople in the Patriarchate of Jerusalem, in

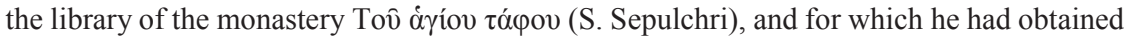
permission to use it in Heidelberg. ${ }^{47}$ In 1842, the same year as the review, he had published a specimen of what would be in store, with an extensive description of the codex. ${ }^{48}$ If Heimbach resented what others might have considered an interference with his project, he did not show it. Rather he welcomed the improvement on his own edition, in which books

44 W. Fischer, 'Zachariä von Lingenthal (24. Dez. 1812 - 3. Juni 1894). Lebensbeschreibung', Bursians Jahrbücher über die Fortschritte der klassischen Alterthumswissenschaft 99 (1898), 14-48, also in K.E. Zachariä von Lingenthal, Kleine Schriften zur römischen und byzantinischen Rechtsgeschichte. Sammlung der in Zeitschriften und Serienwerken erschienenen selbständigen Abhandlungen 18401894. Band I: 1840-1879, (Opuscula. Sammelausgabe seltener und bisher nicht selbständig erschienener wissenschaftlicher Abhandlungen, Band IV/1), Leipzig 1973, 3-37; bibliography by W. Fischer, SZ 16 (1895), 320-332 and supplement in SZ 17 (1896), 332-334, both also in Zachariä, Kleine Schriften, I, 38-53.

45 Kritische Jahrbücher für deutsche Rechtswissenschaft 6 (1842), 481-509.

46 C.E. Zachariae a Lingenthal (ed.), Supplementum editionis Basilicorum Heimbachianae, libros XVXVIII Basilicorum cum scholiis antiquis integros nec non librum XIX Basilicorum novis auxiliis restitutum continens, Lipsiae 1846; cf. also Stolte, Praefatio 2017 (note 8 above), section 3: 'The manuscript tradition of the Basilica', with note 19.

47 Zachariä, Supplementum (note 46 above), Prolegomena; Heimbach, Prolegomena, 166-167. Fischer, 'Lebensbeschreibung' (note 44 above), 28 (= Zachariä, Kleine Schriften, I, (note 44 above), 17).

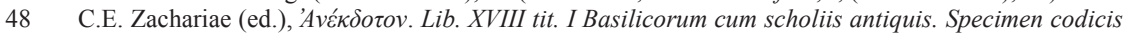
palimpsesti Constantinopolitani Bibliothecae S. Sepulchri, qui solus libb. XV-XVIII Basilicorum integros cum scholiis continet, muneris professoris extraordinarii in Academia Ruperto-Carolina rite capessendi causa edidit, prolegomenis, versione Latina et adnotationibus illustravit..., Heidelbergae 1842; cf. also Stolte, Praefatio 2017 (note 8 above), section 3: 'The manuscript tradition of the Basilica', with note 22 . 


\section{STOLTE}

XV-XVIII had not yet been able to benefit from this palimpsest, ${ }^{49}$ and his own fifth volume (1850) shows that he had profited from Zachariä's criticism.

The second supplement is not by Heimbach or Zachariä, but, more than thirty years after Heimbach's death, was edited by Mercati and Ferrini as the seventh volume of the Heimbach edition of the Basilica. ${ }^{50}$ It contains the so-called Florilegium Ambrosianum, one of the most important indirect witnesses of the Basilica text.

Heimbach's death in 1865 also prevented him to have the satisfaction of seeing his Prolegomena published. They were found in his desk, written in Latin of course, and published posthumously five years later. ${ }^{51}$ Their content covers much more than the usual preliminary material of a critical edition. Indeed, the larger part consists of a history of the sources of Byzantine law. That is not to say that the subject of Heimbach's Prolegomena was unimportant or in any sense mistaken. On the contrary, it was much needed at the time and as such a piece of incredible scholarship. Their contents, however, have been largely superseded by the histories of the sources of Graeco-Roman or Byzantine law that have been written in various modern languages, ${ }^{52}$ and several of Heimbach's conclusions have been modified or even refuted by the evidence of the new edition anyway. ${ }^{53}$

The Prolegomena are followed by a Manuale Basilicorum, another admirable achievement of 19th-century scholarship. It continues the pagination of his Prolegomena, with which it is often found bound in the same volume. The Manuale gives for every chapter of

49 Heimbach, Prolegomena, 167: 'de cuius editione pretio et in quo reliquis [i.e., his own edition! BS] antecellat, infra dicetur'. See Zachariä's Prolegomena to the Supplementum (note 46 above).

50 C. Ferrini / J. Mercati (edd.), Basilicorum libri LX, Volumen VII. Editionis Basilicorum Heimbachianae supplementum alterum. Reliquias librorum ineditorum ex libro rescripto Ambrosiano (praefationem versionem Latinam notas appendices addidit E.C. Ferrini), Lipsiae 1897.

51 Basilicorum libri LX. Post Annibalis Fabroti curas ope codicum manuscriptorum a Gustavo Ernesto Heimbachio aliisque collatorum integriores cum scholiis edidit, editos denuo recensuit, deperditos restituit, translationem latinam et adnotationem criticam adiecit... Tomus VI: Prolegomena et Manuale Basilicorum continens, Lipsiae 1870 (partial reprint Amsterdam 1962), with a monitum bibliopolae, the last paragraph beginning with Ita nos hereditario officio satisfecimus ..., without identifying nos.

52 P.E. Pieler, 'Byzantinische Rechtsliteratur', in H. Hunger (ed.), Die hochsprachliche profane Literatur der Byzantiner, II, (Handbuch der Altertumswissenschaft, XII,5,2), München 1978, 341-480; N. van der Wal / J.H.A. Lokin, Historiae iuris graeco-romani delineatio. Les sources du droit byzantin de 300

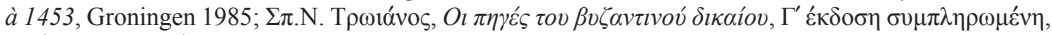
A $\theta$ ๆ́ $\alpha /$ Ko (D. Simon / S. Neye, 2017), in both cases with additional bibliography.

53 The Basilica Online Bibliography by Thomas van Bochove offers an update of literature on most of the subjects dealt with by Heimbach; for the link to the Bibliography, see note 8 above. 
the Justinianic Corpus iuris the corresponding fragments of Byzantine scholarship as preserved in the Basilica and other sources, with their alleged authors if transmitted. At the moment the Manuale is still the best we have, much valued also by Scheltema. ${ }^{54}$

In 2002 Fausto Goria summed up the merits and defects of the Heimbach edition in a short paper, first published digitally, and now accessible in his Scritti scelti. ${ }^{55}$ It was occasioned by the plan for an online publication of the Heimbach edition, and is an excellent and balanced account of the do's and don'ts for those who wish to use Heimbach's edition instead of Scheltema's. It is, in effect, an advice not to use the former independently, but always in combination with the latter as the standard against which to measure its reliability. If a passage is not found in the Groningen edition, the reader must start from the assumption that it does not belong to the Basilica. If it is, he must check whether it reads the same as in Heimbach. Conversely, if the Scheltema edition contains more or has a different reading, Heimbach's translation will be lacking or mistaken. The advantages of still using the Heimbach edition are the Latin translation, the printing of scholia on the same page as the text, the Manuale Basilicorum, and the references made to the edition by scholarly literature for more than a century. Goria ends with a series of warnings ('... non si stancherà abbastanza di repetere che tale edizione va usata con molta cautela e va sempre confrontata con quella successiva. Come è già in parte accennato, essa soffre infatti di numerose manchevolezze, delle quali occorre sottolineare per lo meno le seguenti:' [9-10 = 683-684]). He lists these defects in eight paragraphs, which I follow here to make clear the differences between the two editions. I first paraphrase, without comment, Goria's words:

1. Heimbach had not been able to collate manuscripts himself, but had to rely on collations made by others.

2. In order to save time, 'no fresh collation was made to check Fabrot's edition against manuscripts he had used, also when these could be identified (something that was not always possible); thus it could happen that Heimbach in one of his precious notes presents as his own conjecture the exact reading of the manuscript used by Fabrot, but misunderstood by him or corrupted by a printing error; therefore, there is no doubt that the Heimbach edition in large part (except the observations found in the annotations) reproduces that of Fabrot'.

54 See H.J. Scheltema, 'Ueber die angebliche Anonymuskatene', TRG 25 (1957), 284-301, esp. 296-297 = Scheltema, Opera minora (note 9 above), 315-326 (323-324).

55 F. Goria, 'I "Basilici" e l'edizione di K.-W.-E. Heimbach', Collana della "Rivista di Diritto Romano" - Testi, http://www.ledonline.it/rivistadirittoromano/basilici.html, repr. in P. Garbarino / A. Trisciuoglio / E. Sciandrello (a cura di), Diritto romano d'Oriente. Scritti scelti di Fausto Goria, Alessandria 2016, 681-685. 
3. Where transcriptions or collations have been made - by others -, this has often not been done with the necessary accuracy, especially with scholia.

4. Regularly it occurs that, as a result of mistakes made by Fabrot or one of Heimbach's collaborators, two or more scholia are edited as one scholion, whereas originally they were separate and belonged to different authors or even different epochs.

5. The editor fails to indicate the position of the scholia in the manuscripts (also because [cf. above, sub 1] he did not know it himself), which is an impediment to seriously studying the possibility that they, at least in part, had been assembled systematically in 'catenae' according to a well-known hypothesis by Peters, a hypothesis rejected by Scheltema (who therefore considered it superfluous to provide such indications in his own edition).

6. Heimbach did not indicate the scholia he considered as 'old', i.e. belonging to the sixth and seventh centuries and not commenting on the Greek Basilica text, but on the original Latin texts (indications not found in Scheltema's edition, either).

7. The fact that scholia from different manuscripts are found indiscriminately after each passage does not permit a detailed study of the conditions of their transmission, nor to trace possible different editions of the apparatus these scholia constitute.

8. For the reconstruction of lost books Heimbach often has not used all the testimonia; moreover, sometimes, in vols. i-iv, he reports passages that do not necessarily represent the genuine text of the Basilica, but simply their content ('a fact that for the reader also might have a positive side ...'). In the meantime, it no longer suffices to check the Groningen edition, since other testimonies of the Basilica have surfaced.

As has been said, these eight points are an excellent summary of criticism that may be levelled at Heimbach's edition. Most of it, in fact, is identical with the very motivation for Scheltema to undertake a new edition. The first four points need not occupy us here. They are the reason why Scheltema from the start insisted on fresh and full transcriptions and collations, necessitated in any case by manuscripts discovered since the days of Heimbach, Zachariä and Ferrini, and especially the palimpsests. Even with testimonia it was often considered necessary not to rely on existing editions, but to check the underlying manuscripts. ${ }^{56}$ As to the other four points, some additional comment seems to be called for:

ad 5: As to the position of scholia in the manuscript from which they have been edited, in the Groningen edition, beginning with vol. B II it has been indicated by asterisk $\left(^{*}\right)$ when a scholion has been written in the margin by a more recent hand, and by a paragraph sign (§) when a scholion has been written between the lines in a smaller script. Where no sign has 
been placed, one may assume that scholia are written in the margin, in the order in which they occur. These come first, followed by the two categories indicated by * or $\S$. This, in combination with the separate edition of scholia from more than one manuscript (see also above, Goria's point 7), goes a long way to convey an idea of the location of scholia on the page. For an accurate picture one has to go to the manuscripts themselves, which has become a real possibility thanks to the efforts of libraries to make the images available on the internet.

ad 6: This has been, and still is, a point of discussion. Some criteria give a fairly safe indication that a scholion is 'old', but there are too many uncertainties to decide ex cathedra. ${ }^{57}$ ad 7: See my comment, ad 5.

ad 8: Heimbach had admitted to his reconstructed text in vols i-iv in principle all Greek texts that in one way or another represented a fragment of the Corpus iuris. In so doing he prepared in effect his Manuale Basilicorum, which, in addition to texts from the Basilica, also listed texts from other Byzantine collections. ${ }^{58}$ Heimbach had taken Zachariä's criticism on this way of restitution of lost text to heart and proceeded differently in volume $\mathrm{v} .{ }^{59}$ As to the discoveries of text and scholia since the completion of the individual volumes of the Groningen edition, the fundamental question an editor has to ask himself is the same: almost none of these are part of the direct transmission of the Basilica, but most occur in what are at best testimonia: anthologies, abridgments, commentaries etc. Especially a scholion transmitted with such an indirectly transmitted text is formally still a scholion of that text, not of the Basilica. Although there is a good chance that several are in fact genuine testimonia, scholarly prudence may prevent their inclusion in an edition of the Basilica. ${ }^{60}$

\section{The present: H.J. Scheltema (1906-1981)}

It may look strange to describe the present by the name of a scholar who undoubtedly belonged to the twentieth century and in certain respects preferred the nineteenth. But he definitely is the present as far as the edition of the Basilica is concerned. With the discussion of the shortcomings of Heimbach's edition at the end of the previous section we have silently and inescapably entered upon Scheltema's edition. There is no reason to repeat my description of the principles of this edition in the online Praefatio that is based on Scheltema's prefaces to the individual volumes and his papers. Rather I would like to consider it against

57 This was Scheltema's view; see Stolte, Praefatio 2017 (note 8 above), sections 5.1 and 5.3 sub 1.

58 Stolte, Praefatio 2017 (note 8 above), section 1.

59 Stolte, Praefatio 2017 (note 8 above), section 5.1.

60 Stolte, Praefatio 2017 (note 8 above), section 5.3 sub 3. 
the background of what had inspired the inception of his life's work and then to look at his achievement.

First, Scheltema was interested in Roman law, in the Justinianic legislation, and in its influence on modern legal doctrine. Less interested than most of his contemporaries in a recuperation of supposedly corrupted 'classical' Roman legal texts, he first of all wished to have an accurate knowledge of the sixth-century codification, a knowledge which he saw that Byzantine sources, in particular the Basilica and their scholia, had so much to contribute to. To be sure, this was not a new thought. It had been the inspiration of scholarship since the Humanists, and the motivation of Heimbach had been the same. What was new was Scheltema's insight in the shortcomings of Heimbach's edition for precisely that purpose: providing access to a huge amount of Greek fragments written by jurists who had collaborated in drafting Justinian's codification, had translated, summarized and commented upon Institutes, Digest, Code and Novels, and taught in the class-rooms of the law schools of that age. Hence the emphasis on the potential of the 'old' scholia for, as it were, enabling the modern scholar to sit in these class-rooms. Again, not a new thought, but Scheltema had a better grasp of the extent of that potential and knew that it could be developed only fully if first a reliable edition of the main source, the Basilica cum scholiis, was made available. One only has to read the first sentence of his 1939 paper 'Probleme der Basiliken':

Eine Neuausgabe der Basiliken lässt noch auf sich warten, obwohl sie zu den dringendsten Aufgaben der heutigen Romanistik gehören dürfte. ${ }^{61}$

In his view it was a problem of the 'heutige Romanistik' [my emphasis, BS], but one that could only be solved by making an edition according to the philological standards of his time. Fabrot's edition, and in large part also still Heimbach's, were essentially products of the philology of a bygone age. For a new edition the 'heutige Philologie' was called upon to assist.

The result is an edition that diverges considerably from Heimbach's in several respects. (I pass by the differences which immediately strike the eye: the lack of a translation and the separation of the scholia from the texts to which they refer, the scholia of each manuscript kept separate. ${ }^{62}$ ) The criticisms listed by Goria and discussed above speak for themselves; these were the points on which Scheltema had found the available edition wanting and had set out to remedy these defects. One therefore supposes, indeed correctly infers, that these are the differences between the two editions. Yet Heimbach's edition has

61 TRG 16 (1939), 320-346 (320) = Scheltema, Opera minora (note 9 above), 170-188 (170).

62 See Stolte, Praefatio 2017 (note 8 above), sections 1 and 5.1. 
remained in continued use. No doubt its Latin translation is the main reason, but a translation is at best a good representation of the text on which it is based, and the text of the edition of Scheltema cum suis is different indeed. It makes relying on Heimbach's translation very hazardous. Here are again, very briefly, the main factors which caused the new edition to be different:

1. Scheltema used more manuscripts, especially palimpsests;

2. Scheltema made fresh and full collations of all manuscripts;

3. Scheltema used more testimonia and a different method of reconstruction of lost text.

Goria has warned against uncritically using Heimbach's edition. ${ }^{63}$ Here a few concrete examples may follow by way of illustration of what the difference amounts to.

\section{a. Book VIII}

This is a book with a troubled editorial history. Book VIII has been transmitted in four manuscripts: Paris. gr. 1352 (P), Leiden Voss. gr. Fol. 19 (V), Scorialensis R II 13 (H), and Coisl. gr. 151 (Cb). The Coislinianus is the only one without scholia; $\mathbf{V}$ and $\mathbf{H}$ shared the same apparatus, whereas $\mathbf{P}$ had an entirely different, much more concise set of scholia. The third-mentioned manuscript, the Scorialensis, has a somewhat obscure past. It is a copy of an older manuscript, almost certainly also in the Escorial but now lost, and was finished on March 6th 1574 by Andreas Darmarios. In the beginning of the 19th century it was in the possession of Gustav Haenel (hence the siglum $\mathbf{H}$ ) and collated by Heimbach. ${ }^{64}$ Haenel later discovered that it had been stolen from the Escorial and returned the codex to its rightful owner, but that seems to have made it disappear for a time from public knowledge as well. Heimbach did not know where it was in $1864,{ }^{65}$ nor did initially Scheltema when he was preparing the first volume of his edition. In fact, already in 1880, Charles Graux had seen it in its original and present abode, the library of the Escorial, and pieced together its probable history ${ }^{66}$ Only opere iam absoluto, i.e., after editing the scholia of book VIII in vol. B I

63 Goria, 'I "Basilici” e l'edizione di K.-W.-E. Heimbach' (note 55 above), 9 = Goria, Scritti scelti, 683.

64 Heimbach, Vol. I, 323, n. $a$ ad Bas. VIII.

65 K.W.E. Heimbach, 'Mittheilungen über die bei der Heimbach'schen Basilikenausgabe benutzten Handschriften', ZRG 4 (1864), 299-346 (320-324, esp. 324); cf. Heimbach, Prolegomena, 166. (The article is almost entirely a German version of the coresponding part of the Prolegomena.)

66 Ch. Graux, Essai sur les origines du fonds grec de l'Escorial. Episode de l'histoire de la renaissance des Lettres en Espagne, (Bibliothèque de l'École des Hautes Études, Sciences philologiques et historiques, fasc. 46), Paris 1880, 327-328; for a description of the manuscript, see P.A. Revilla, Catálogo de los Códices Griegos de la Biblioteca de El Escorial, I, Madrid 1936, No. 32, pp. 135-136. 
from the Vossianus, was Scheltema alerted by Ms Hulshoff Pol to the existence of $\mathbf{H},{ }^{67}$ and inserted its variae lectiones on two pages into the preliminaries of that volume, where he also gave his opinion that $\mathbf{V}$ had been copied from $\mathbf{H} .{ }^{68}$ For the text of book VIII he was able to include $\mathbf{H}$ in the critical apparatus of vol. A I.

As has been said above, Fabrot had edited book VIII from the Parisinus, and Ruhnkenius had done this from the Vossianus. Thus, inadvertently of course, they had anticipated Scheltema's editorial principle of keeping the scholia of individual manuscripts separate. The scholia apparatus of $\mathbf{V}$ and $\mathbf{H}$ is far more interesting than that of $\mathbf{P}$, especially if the reader is interested in the jurisprudence of the sixth century. Heimbach, of course, shared this opinion and noted that he could not really amalgamate the apparatus of $\mathbf{P}$ and $\mathbf{H} / \mathbf{V}$; however, he did not clearly distinguish the two. ${ }^{69}$ Heimbach had thought that $\mathbf{V}$ and $\mathbf{H}$ went back to a common archetype, Scheltema concluded that $\mathbf{V}$ had been copied from $\mathbf{H}$. Neither Fabrot nor Ruhnkenius had been very accurate. Heimbach had largely followed Ruhnkenius and given readings from $\mathbf{H}$ in the footnotes. ${ }^{70}$ The reader who now wishes to consult book VIII and its scholia has to use the text in vol. A I, follow the references to the scholia of $\mathbf{V}$ and of $\mathbf{P}$, read those in vol. B I, and check in individual cases also the variant readings from $\mathbf{H}$ in B I at pp. viii-ix. They start from the printed scholia of $\mathbf{V}$, assuming that $\mathbf{H}$ has the same scholia as its codex descriptus $\mathbf{V}$, and, where the apparatus referred to 'Cod. Haen.' via Heimbach, report numerous corrections. ${ }^{71}$ Moreover they give from $\mathbf{H}$ scholia additional to those in $\mathbf{V}$, scholia which are in $\mathbf{V}$ but form in $\mathbf{H}$ more than one scholion, or show variants in $\mathbf{H} .^{72}$

67 Hulshoff Pol, Studia Ruhnkeniana (note 31 above), 103; Scheltema, A I, Praefatio, p. v-vii.

68 Scheltema, B I, Praefatio. p. viii-ix.

69 Heimbach, Prolegomena, 164-166.

70 Also in the footnotes readings attributed to a manuscript of Theodorus of Hermopolis ('Theod.'). This is in fact the Ecloga Basilicorum, wrongly attributed to this Theodorus in cod. Paris. gr. 1358. See L. Burgmann (Hrgb.), Ecloga Basilicorum, (Forschungen zur byzantinischen Rechtsgeschichte, Band 15), Frankfurt/M. 1988, Einleitung, p. viii. Heimbach had used a copy of the Parisian manuscript lent to him by F.A. Biener, the present Leipzig UB, ms 41 [RHBR, I, No. 98]. See Heimbach, Vol. I, preface Lectori benevolo, p. xi, and at p. 323 n. $a$ ad Bas. 8,1.

71 E.g., 'p. [BS] 61 app. crit ad 1. 9: dele verba "Cod. Haen. $\zeta v^{\prime} . "$.'

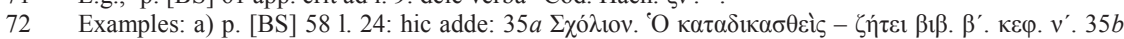

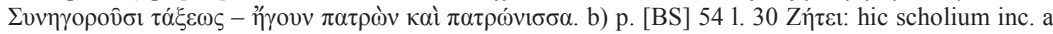

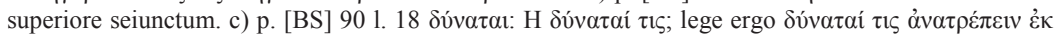
$\beta \alpha \sigma \iota \lambda \iota \kappa \hat{\varsigma} \varsigma \dot{\alpha} v \tau \imath \gamma \rho \alpha \varphi \hat{\varsigma}$. 


\section{THIRTY YEARS LATER}

\section{b. B. XXX,1}

Book XXX has been preserved in only one manuscript, Paris. gr. 1348, which breaks off in B. XXX,1,7,5 = D. $24,1,7,5$ (see app. crit. ad BT 1509/21). Heimbach has at this point the following note $p$ :

After the word $\delta \alpha \pi \alpha v \eta \theta \dot{v} v \tau \omega v$ Fabr(ot) vol. IV p. 739 notes: "Thus far the exemplar Regium [Cod. Paris. 1348].” The rest that is lacking up to book 38 we have supplied from the Synopsis Basilicorum collated with manuscripts, as well as from Greek interpretes (scholiasts) and

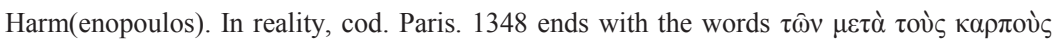
$\pi \varepsilon p i$. For the restitution of the remaining part of this book, I have used, in addition to Syn. and Harm., scholia of the Basilica and above all Tipuciti Paratitla [the Tipucitus], from which almost everything that is lacking can be supplemented. The way of restitution has been this, that I placed an stellula (asterisk) before those fragments, which can be proved to contain the genuine text of the Basilica, and the rest placed at the apposite numbers with the source from which they have been taken.

Comparing Heimbach's treatment of the rest of B. XXX,1 until the end of the Digest part, i.e. coresponding with D. 24,1,7,5-eod. 67, with Scheltema's, the following picture emerges: Heimbach considers thirteen of the 57 fragments he includes to be genuine. The number 57, that is in Heimbach's numbers from $\zeta^{\prime}$ up to and including $\xi \gamma^{\prime}$, is entirely arbitrary, since there is no way of reliably numbering reconstructed passages, as manuscript evidence is by definition lacking, and numbers are notoriously erratic in the first place. In fact, Heimbach gives more than 57, since in some cases, where more possible candidates for representing the Basilica text have been preserved, he gives all of them: see, e.g., Heimbach, Vol. IV, p. 509, under No. $\mu \eta^{\prime}=24,1,51$, where he has three Greek fragments (numbered 1, 2 and 3) and explains (notes $y, z$ and $a$ ) that they have been drawn from Attaliotes 30,4; Tipucitus, and Harm. IV,9,10 respectively. In the last note he adds: 'Neglexit hunc locum Fabrotus'. Scheltema 'neglected' this passage, too, since he was unconvinced that any of the three passages had preserved the genuine Basilica text. What Heimbach had done was not so much reconstructing lost Basilica text as compiling, as fully as possible, a file of Greek equivalents of the pertinent Digest text. Scheltema gives no textus restitutus for the leges 8 , $12,16-18,20,29-30,33,35,38-39,46-47,49-52,54,57,59,61-62$ and $64-67$ of this title, and of the other ones often only a part. Of these, only of 16,30,47, and 62 remain without a Greek passage in Heimbach. ${ }^{73}$

73 Heimbach had already been criticised by Zachariä for this method, as mentioned by Van der Wal, 'Probleme bei der Restitution' (note 30 above), 144 n. 5. 


\section{c. $B . X I, 1,1=D .2,14,1$}

Finally, a brief comparison at micro level. Looking closer at the same example used for a guide to the use of the Groningen edition, ${ }^{74} \mathrm{~B}$. XI, $1,1=$ D. $2,14,1$, we may observe that in the same line 5 of the text, Ca has Ulpian in the inscription as Latin 'UlPI', whereas $\mathbf{P}$ writes

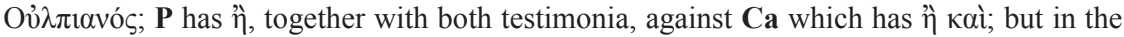

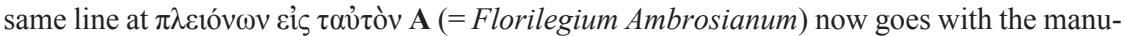

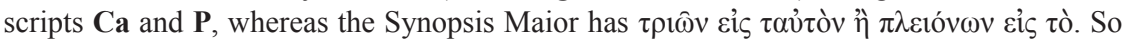
what is the difference with Heimbach's edition at the same point (Vol. I, p. 553)?

Both editions have the same text, except the inscription: Ulpi Scheltema, Ov̉ $\pi$. Heimbach. Heimbach presents all remarks on the Greek text as lettered footnotes ( $a, b$ etc.); the Latin translation has numbered references $(1,2$ etc.) to the scholia. These are, in the column with Greek, preceded by a lemma (e.g., $\sigma 0 ́ \mu \varphi \omega v o ́ v)$, in turn rendered in the column with the Latin translation by a Latin equivalent (in this case, pactum). These, of course, are no more than typographical choices. But Heimbach's choice of Ov $\lambda \pi$. is not without significance. He made much of his use of the Coisliniani, which he considered his major contribution. Here, in footnote $a$ at the rubrica of this title he writes that $\mathbf{C a}$ is cum scholiis uberrimis, quae nunc primum typis excuduntur, and hic potissimum ad emendandam et supplendam Fabrotianam editionem adhibitus est. Yet the Coislinianus gr. 152 (Ca) has UlPI; Ovं $\lambda(\pi 1 \alpha-$ vós) is the reading of the Parisinus, which had been used by Fabrot. From the treatment of other inscriptions in this title it appears that Heimbach systematically corrected Fabrot with the help of the Coislinianus, but did not pay attention to the Latin letters in Ca. But crucially, he does not seem to have made a fresh collation of $\mathbf{P}$. If he points out a difference between the Coislinianus and another reading, he usually quotes Fabrot instead of the Parisinus, following the pattern of: ' $\alpha \alpha \alpha$ ' Cod. or Cod. Coisl., ' $\beta \beta \beta$ ' Fabr.; or :' $\alpha \alpha \alpha$ ' Cod., deest apud Fabr.

The greatest difference, however, consists in the treatment of the scholia. The same note a continues as follows: Scholia antiquiora in Cod. [Coisl.] exhibita nullo signo distinxi; scholia recentiora hoc Cod. comprehensa signo stellulae notavi. Praeter scholia hoc Cod. ms. comprehensa excudenda etiam curavi scholia a Fabroto communicata eaque signo crucis $\uparrow$ notavi, ut discernerentur ab iis, quae in Cod. Coisl. exhibentur. Thus we may expect a distinction between old and new scholia from the Coislinianus and a distinction between scholia already in Fabrot (i.e., in principle the Parisinus) and those from the Coislinianus. Looking at the scholia ad B. XI,1,1 pr. in both editions, the following picture emerges.

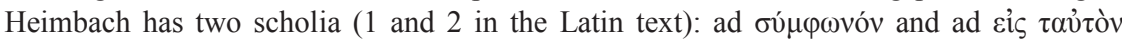




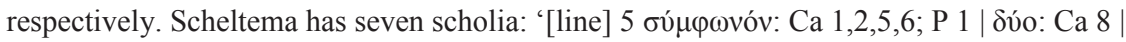

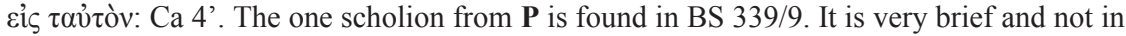
Heimbach; it was lacking in Fabrot, too. Heimbach's first scholion corresponds with part of

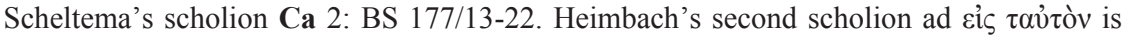
Scheltema's Ca 4: BS 178/35-37. Scheltema's Ca 5, 6 and 8 are lacking altogether. The

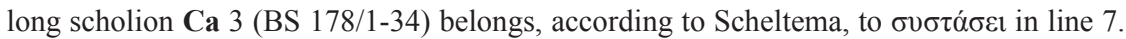

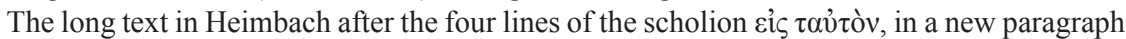

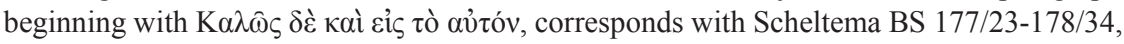
that is the continuation of Scheltema Ca 2 plus a separate scholion Ca 3. To sum up, scholia now in the Groningen edition are in Heimbach either lacking or distinguished differently, which obviously may give rise to different attributions of portions of text. In the present

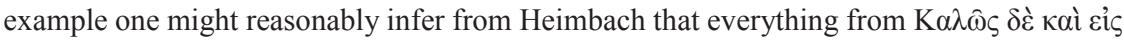

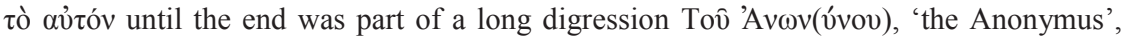
which however is not warranted by the manuscript tradition.

These are just a few observations bearing on two lines of text with their scholia, which I have selected partly at random, partly on purpose. At random, since I had once read the numerous scholia of B. XI,1 and thought I might as well begin at the same point; on purpose in the sense that I then checked whether Scheltema had ever used these lines and their scholia to demonstrate where progress could be made, which he had not. The printed edition of the Basilica consists of 3131 pages of text, each page numbering circa 20 lines. Two vs 62,620 lines: the numbers speak for themselves.

\section{The future?}

In the Praefatio of the online edition I have given a survey of discoveries made after the completion of the Groningen edition ${ }^{75}$ and written as the final sentence of the Epilogue: 'Obviously, work has not ended here'. Rather than outlining an ambitious programme, I would like to touch briefly on two points which I consider important for future work.

First, the online format makes it possible gradually to compile a volume of Addenda, and for some time to abandon any thoughts of a definitive publication. While I would strongly advocate to leave the original work intact and not to change anything in online version of the seventeen volumes as they have been printed, the flexibility of online publication of work-in-progress should perhaps be taken advantage of. 


\section{STOLTE}

Second, the discovery of an early witness of the Basilica in the lower layer of codex Vindob. Suppl. gr. 200 has given rise to a reconsideration of the early history of the text. Tom van Bochove has argued for it to be a representative of the Sixty Books in four $\tau \varepsilon v ́ \chi \eta$ of Basil the Macedonian as opposed to the Basilica of Leo the Wise, together with the Florilegium Ambrosianum, the Paris. gr. 1357, the lost manuscript of Cujas ('codex Ridolfi'), and the Coisl. gr. 151 including the Index titulorum of all sixty books at its ff. 1-18 (ICb). ${ }^{76}$ If he is right, this view undermines the foundation of all editions since Fabrot and we would have to accept that a sizable portion of the witnesses of these editions cannot be taken to belong to the direct transmission of the Basilica. At the same time, I would venture to suggest that the differences regard the outward characteristics of the transmission, but not the substance of the text. That, however, remains to be seen and its investigation belongs to the future.

Groningen University

Bernard H. Stolte

76 Th.E. van Bochove, 'Preluding the Basilica, but how? The final paragraph of preface to the Prochiron reconsidered', SG IX (2014), 267-318. The part pertinent to the present subject is summarized at p. 317. 